\title{
REDUÇÃO DE ATRASOS PARA PRIMEIRAS CIRURGIAS
}

\section{INTRODUÇÃO}

Importante enfatizar que o processo de internação do pacienteconta com a agilidade e segurança da Instituição em garantir a qualidade do serviço prestado e humanização no atendimento. Com o intuito de garantir a satisfação do cliente, o Hospital Unimed Araçatuba promoveu a antecipação das internações cirúrgicas eletivas. Organizou o conceito de que este processo é extremamente importante para reduzir/eliminar atrasos nas cirurgias dos primeiros horários e coopera para satisfação dos clientes, da equipe de enfermagem e corpo clínico.

\section{OBJETIVO}

Eliminar atrasos de cirurgias, maximizar a admissão e acolhimento do paciente mantendo a organização no cumprimento dos horários conforme estipulado pelo Centro Cirúrgico e mencionados na agenda, garantindo segurança e satisfação dos clientes.

\section{METODOLOGIA}

Através da pré-internação os pacientes, com cirurgias eletivas agendadas às 7:00 h da manhã, são orientados a comparecer no hospital, dando entrada pela recepção do Pronto Atendimento, entre 5:00 h e 6:00 h para realização da internação. Os colaboradores (recepcionistas) foram preparados para priorizar dentro deste horário, o atendimento às internações de cirurgias eletivas. Assim os pacientes ao término do processo de abertura do prontuário e após identificação através de pulseiras, são direcionados à equipe de enfermagem do Day Clinic, a qual fará admissão dos mesmos deixando-os prontos para o momento da chamada ao Centro Cirúrgico, que o fará através de uma ligação telefônica ao setor que acolheu o paciente e dará início ao procedimento dentro do horário estimado conforme agenda cirúrgica.

\section{RESULTADO}

Do objetivo proposto em reduzir/eliminar atrasos nas primeiras cirurgias agendadas, há uma aderência de $100 \%$ acatadas no processo junto à Instituição e o paciente/ cliente.

Capacidade de atendimento no período proposto:

\begin{tabular}{|c|c|c|}
\hline $\begin{array}{c}\text { Média de } \\
\text { cirurgias } \\
\text { agendadas } \\
\text { as7h }\end{array}$ & 5 & $\begin{array}{c}\text { Capacidade } \\
\text { Internações: } \\
8\end{array}$ \\
\hline $\begin{array}{c}\text { Tempo para } \\
\text { atendimento }\end{array}$ & $2 \mathrm{~h}$ & $\begin{array}{c}\text { atendimento } \\
\text { por hora: } \\
4\end{array}$ \\
\hline $\begin{array}{c}\text { colaboradoras } \\
\text { disponíveis }\end{array}$ & 2 & $\begin{array}{c}\text { atendimento } \\
\text { por } \\
\text { colaboradora } \\
/ \text { hora: } \\
4\end{array}$ \\
\hline $\begin{array}{c}\text { Tempo por } \\
\text { atendimento }\end{array}$ & 15 min. & \begin{tabular}{c}
120 min. \\
\hline
\end{tabular} \\
\hline
\end{tabular}

\section{CONCLUSÃO}

Satisfação dos clientes pelo atendimento dentro do horário estimado, do corpo clínico pela não ocorrência de atrasos nas cirurgias cumprindo o esperado, da equipe de enfermagem que fará a admissão e acolhimento com maior segurança e cumprimento dos protocolos.

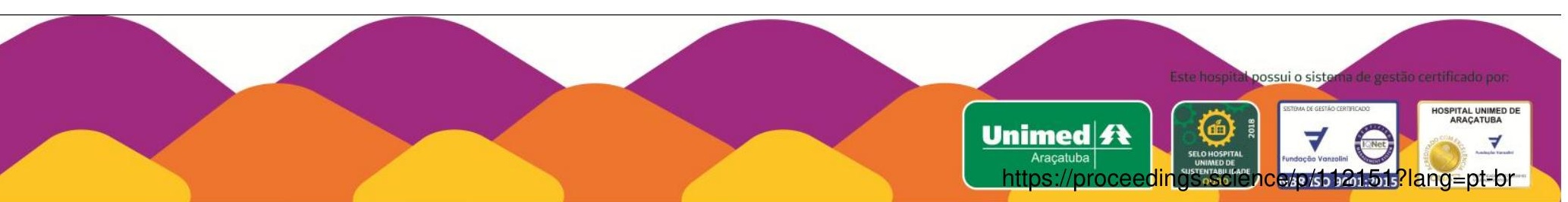

